\title{
連行車両による道路橋の二乗平均応答解析 \\ MEAN SQUARE RESPONSE ANALYSIS OF HIGHWAY BRIDGES \\ UNDER A SERIES OF MOVING VEHICLES
}

\author{
岡 林 隆 敏* -山口実浩** \\ By Takatoshi OKABAYASHI and Zituhiro YAMAGUCHI
}

\section{1. はじめに}

走行車両による道路橋は, 路面凹凸および伸縮継手等 の路面の条件, 車両の動特性（重量, 固有振動数, 減衰 定数), 載荷台数 および 車頭間隔で規定される走行状態 等の不確定な要因により複雑で不規則な振動をする. 近 年, 交通量の増大および車両の大型化に伴い, 道路橋に 作用する荷重はますます増大しつつある. さらに, 橋梁 の長大化，高性能材料の開発掞よび解析手法の発達に伴 って, 橋梁は振れやすくなったといわれている. このよ うな状況のもとで, 衝撃係数, 疲労強度および振動感覚 をより合理的に評価するために，これらの不確定性を考 虑した理論的研究が進められている.

これらの理論解析は, いずれも走行車両による道路橋 の态答解析に基づいて評価されるものであり，各種の不 確定要因による橋梁振動の統計的特性を解析する手法が 提案されてきた. 路面凹凸を確率過程でモデル化し，単 一走行車両による道路橋応答の分散を解析する研究が報 告されている ${ }^{1) ~ 7)}$. 一方, 交通流に着目し, 交通流によ る橋梁応答を理論的にあるいはシミュレーションにより 解析したものもある ${ }^{8) ~ 13)}$. この理論的解析では, 単一走 行車両による解析を交通流による応答に適用したもので ある. また, 実測結果に基づいて衝撃係数を推定する研 究が試みられている ${ }^{14) ~ 16) . ~}$

実際の橋梁では, 支間長が長くなると大型車両が同時 に載荷する可能性は大きくなり, 単一車両だけで道路橋 の状態を推定することは不十分である. また, 道路橋示 方書によれば, 設計荷重は大型自動車列荷重を対象にし ている. 連行車両による道路橋の応答解析については, これまでいくつかの研究が報告されている. 小堀・山 田 ${ }^{1}$ は, 定常不規則応答解析の理論に基づい, いくつ

* 正会員 工修 長崎大学助手 工学部土木工学科

** 政会員 日立造船（株）
かの仮定のもとに連行車両列による道路橋の衝擊係数を 提案した. 小松・川谷 ${ }^{17}$ は, 斜張橋に対する理論的・実 験的研究より, 連行車両による衝撃係数を共振車頭間隔 の考え方で整理している. 梶川 ${ }^{18)}$ は, 交通調查のデータ より道路橋の使用性の検討を行っている. 不規則路面凹 凸上を走行する連行車両による道路橋の振動について, 非定常不規則振動論に基つく理論解析を彦坂・吉村・内 谷 ${ }^{19)}$ は報告している.

路面凹凸上を走行する連行車両で加振 される道路橋 は, 橋梁と車両の連成, 車両間の連成および車頭間隔等 に起因する車両間の相関により, 複雑な連成系となる. この結果, 橋梁は不規則で非定常な応答性状を呈する. このような系に対して, 非定常性を考虑した不規則振動 論に基づく解析は, 彦坂ら ${ }^{19)}$ の研究以外にはみられな い.しかし，この報告では，車両間の連成および車両間 の相関が応答に及ぼす影響について検討されていない. 連行車両による道路橋の振動性状を説明するためには, これらの連成および相関を明確に表現できる解析手法が 望ましい.

本論文では，非定常性，車両間の連成および相関を厳 密に評価する連行車両による道路橋の r.m.s. (root mean square）応答解析の手法を提案した. 本解法の基礎 方程式は, 次のように構成する. 路面凹凸を白色雑音過 程を入力とする一種のフィルター系の出力で 表現する と, 橋梁-連行車両-路面系は伊藤型の確率微分方程式で 記述できる. この確率微分方程式より，橋梁の振動の分 散を表現する共分散方程式を誘導する. マトリックス形 式で記述される本解法によれば，橋梁と連行車両間の連 成および相関を表わす変数関の関係が, 明確に表現でき る.したがって, 車両間の連成および相関を無視した解 析モデルを構成することが可能である. さらに，本解法 では, 非定常応答解析は微分方程式の解法に, 定常応答 解析は連立方程式の解法に帰着する.

単純析橋に本解法を適用し, 連行車両を規定する主要 
なパラメーター，すなわち車両台数および車頭間隔の橋 梁応答に及ぼす影響について検討した. また，非定常応 答解析による最大 r.m.s. 応答を推定する 定常応答理論 による簡便法を提案し，その妥当性について調べた．最 後に, 本解析で得られた結果より衝撃係数を算定し, 現 行示方書および過去の研究において提案された衝撃係数 との関係について述べた.

\section{2. 橋梁-連行車両系の運動方程式と路面凹凸 のモデル化}

\section{（1）橋梁-連行車両系の運動方程式}

不規則路面凹凸を有する橋梁上を， 1 自由度系でモデ ル化された $n$ 台の車両が一定速度 $v$ で走行する模様を 図一1 に示した. この橋梁-連行車両系の運動方程式に ついて説明する.

$n$ 台の車両に対して,時間座標を次のように定義する.

$t_{i}: i$ 台目の車両が進入する時間,

$t_{i j}: i$ 台目の車両と $j$ 台目の車両の車頭間隔時間, 支点から距離 $x$ にある着目点の橋梁の動的たわみ $y(x$, $t$ ） は, $k$ 次固有モードの 基準関数 $\phi_{k}(x)$ と 基準座標 $q_{k}(t)$ により,

$$
y(x, t)=\sum_{k=1}^{\infty} q_{k}(t) \phi_{k}(x)
$$

で表わされる． 橋梁に作用する $i$ 台目の車両の 接地力 を $P_{i}(t)$ とすると, $q_{k}(t)$ は次式により得られる.

$$
\begin{aligned}
\ddot{q}_{k}(t) & +2 h_{k} \omega_{k} \dot{q}_{k}(t)+\omega_{k}^{2} q_{k}(t) \\
& =\sum_{i=1}^{n} P_{i}(t) \phi_{k}\left(v\left(t-t_{i}\right)\right) / M_{k}
\end{aligned}
$$

ここに, $M_{k}=\int_{0}^{L} \rho \phi_{k}(x)^{2} d x$ また $\omega_{k}, h_{k}, \rho$ および $L$ は，それぞれ橋梁の $k$ 次の固有円振動数, 減衰定数, 単位長さ当たりの質量および支間長である. なお，・は 時間微分を表わすものとする.

次に $i$ 台目の車両の運動方程式について述べる. 基準 点から距離 $x$ にある 不規則路面凹凸を $R(x)$ とする と, 一定速度 $v$ で走行する 車両上では，この路面凹凸は 時間関数 $r(t)$ として観測される. この路面凹凸より加 振される 1 自由度系でモデル化された $i$ 台目の車両の運 動方程式は, 車両直下の 橋梁の 動的たわみ $y_{v i}(t)$, 車

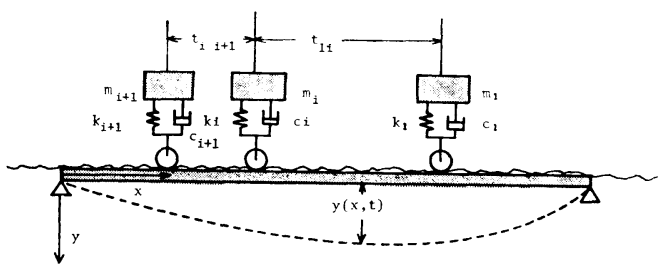

図一1 橋梁-連行車両系
両の垂直変位を $z_{i}(t)$ として,

$$
\begin{aligned}
& m_{i} \ddot{z}_{i}(t)+c_{i}\left(\dot{z}_{i}(t)-\dot{y}_{v i}(t)-\dot{r}\left(t-t_{1 i}\right)\right) \\
& \quad+k_{i}\left(z_{i}(t)-y_{v i}(t)-r\left(t-t_{1 i}\right)\right)=0 . .
\end{aligned}
$$

で記述される.ここに， $m_{i}, c_{i}$ および $k_{i}$ は $i$ 台目の車 両の質量, 減衰定数およびばね定数である.このとき, この車両による接地力は,

$$
P_{i}(t)=m_{i}(g-\ddot{z}(t))
$$

となる.ここで, $g$ は重力加速度である.

$i$ 台目の車両の固有振動数および減衰係数をおのおの $\omega_{0 i}$ および $h_{0 i}$ とすると, 橋梁-連行車両系の方程式は, 改めて

$$
\begin{aligned}
& \ddot{q}_{k}(t)+2 h_{k} \omega_{k} \dot{q}_{k}(t)+\omega_{k}{ }^{2} q_{k}(t) \\
&= \sum_{i=1}^{n} R_{i k}\left(g-\ddot{z}_{i}(t)\right) \phi_{k}\left(v\left(t-t_{i}\right)\right) \\
& \ddot{z}_{i}(t)+2 h_{0 i} \omega_{0 i}\left(\dot{z}_{i}(t)-\dot{y}_{v i}(t)-\dot{r}\left(t-t_{1 i}\right)\right) \\
&+\omega_{0 i}{ }^{2}\left(z_{i}(t)-y_{v i}(t)-r\left(t-t_{1 i}\right)\right)=0 \\
&(i=1, \cdots, n)
\end{aligned}
$$

で表わされる. なお, $R_{i k}=m_{i} / M_{k}$ である.

この橋梁-連行車両系の初期条件は，次のように考え られる．橋梁は先頭の車両が進入するまで静止している ので,

$$
q_{k}\left(t_{1}\right)=\dot{q}_{k}\left(t_{1}\right)=0
$$

となる. 一方, 車両はそれぞれ橋梁に進入するまで，路 面凹凸上を走行している. このとき， $i$ 台目の車両の運 動方程式は,

$$
\begin{aligned}
\ddot{z}_{i}(t) & +2 h_{0 i} \omega_{0 i}\left(\dot{z}_{i}(t)-\dot{r}\left(t-t_{1 i}\right)\right) \\
& +\omega_{0 i}{ }^{2}\left(z_{i}(t)-r\left(t-t_{1 i}\right)\right)=0
\end{aligned}
$$

で与えられる. $i$ 台目の車両の初期条件は，この方程式 において先頭の車両が橋梁に進入する直前の值

$$
z_{i}\left(t_{1}\right)=z_{0 i}, \dot{z}_{i}\left(t_{1}\right)=\dot{z}_{0 i}
$$

である．路面凹凸を確率過程でモデル化すると，これは 確率変数 となる. 伸縮継手等の 路面形状に関する条件 は，路面凹凸関数 $r(t)$ をモデル化することにより解析 の中に組み込むことは可能である。

\section{（2） 路面凹凸のモデル化}

路面凹凸は，平均值（，パワースペクトル密度

$$
S_{R}(\Omega)=A \Omega^{-n}
$$

を有する正規性定常確率過程でモデル化することができ る.ここに， $\Omega, A$ および $n$ は，それぞれ単位長さ当た りの凹凸数, 路面凹凸の良否を表わす定数およびパワー スペクトル密度の形状を表わす指数である. 走行車両上 から観測した 路面凹凸のパワースペクトル密度は, $n=$ 2, $A=1.0 \times 10^{-3}\left(\mathrm{~cm}^{2} / \mathrm{mC}^{-1}\right)^{21)}$ の値を有する.

$$
S_{r}(\omega)=A v /(\omega / 2 \pi)^{2}
$$

の形が従来用いられている. な拉， $\omega=2 \pi v \Omega$ の関倸が 
ある. 近年，路面凹凸の実測が行われ，資料が整備され つつある(14),18),20).

本論文で提案する解法では, 路面凹凸を路面系と称す る常微分方程式

$$
\dot{r}(t)+\beta r(t)=w(t)
$$

の定常解過程でモデル化する ${ }^{5), 6)}$.ここに $w(t)$ は次のよ うな確率特性で規定される正規性白色雑音過程である.

(i) $\mathrm{E}[w(t)]=0$

(ii) $\mathrm{E}\left[w\left(t_{1}\right) w\left(t_{2}\right)\right]=S_{0} \delta\left(t_{1}-t_{2}\right)$

ただし， $\mathrm{E}[$ ] は集合平均のための演算子である. $\delta(t)$ は Dirac のデルタ関数である. 路面系の解過程の平均 值と分散は，それぞれ 0 および $S_{0} / 2 \beta$ となり，そのパ ワースペクトル密度は,

$$
S_{r}(\omega)=S_{0} /\left(\omega^{2}+\beta^{2}\right) \text {. }
$$

で与えられる. ここに， $\beta=2 \pi v a ， S_{0}=(2 \pi)^{2} v A$ であ る. なお， $a$ は式 (11) に適合させるために $a=0.05$ と した. 図一2 は, 川合・森崎 ${ }^{21)}$ の実測結果と本解法に用 いるパワースペクトル密度を図示したものである.

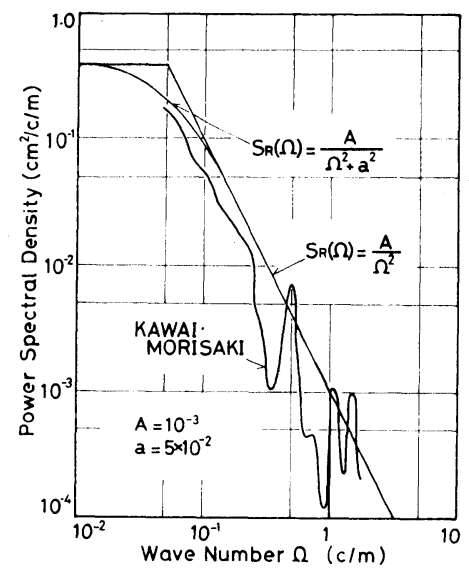

図一2 路面凹凸のパワースペクトル密度

\section{3. 橋梁-連行車両-路面系の状態空間表示}

本論文では，橋梁の力学モデルとして，2 次以上の高 次振動を無視した 1 自由度系を仮定する. 高次振動を考 慮した一般的な解析に対して，本解法を適用することは 可能である. 橋梁系の状態変数 $\boldsymbol{Y}(t)$ を $m_{1}(=2)$ 次元

$$
\boldsymbol{A}_{\boldsymbol{Y}}(t)=\left[\begin{array}{cc}
0 & 1 \\
-\omega_{1}{ }^{2}-\sum_{i=1}^{n} \omega_{0 i}{ }^{2} R_{i 1} \phi_{1}\left(v\left(t-t_{i}\right)\right) u\left(t-t_{i}\right) & -2 h_{1} \omega_{1}-\sum_{i=1}^{n} 2 h_{0 i} \omega_{0 i} R_{i 1} \phi_{1}\left(v\left(t-t_{i}\right)\right) u\left(t-t_{i}\right)
\end{array}\right]
$$

$$
\boldsymbol{A}_{\boldsymbol{Y Z} i}(t)=\left[\begin{array}{lc}
0 & 0 \\
\omega_{0 i}{ }^{2} R_{i_{1}} \phi_{1}\left(v\left(t-t_{i}\right)\right) u\left(t-t_{i}\right) & 2 h_{0 i} \omega_{0 i} R_{i 1} \phi_{1}\left(v\left(t-t_{i}\right)\right) u\left(t-t_{i}\right)
\end{array}\right.
$$

0

$\left.\left(2 h_{0 i} \omega_{0 i} \beta-\omega_{0 i}{ }^{2}\right) R_{i 1} \phi_{1}\left(v\left(t-t_{i}\right)\right) u\left(t-t_{i}\right)\right]$ 


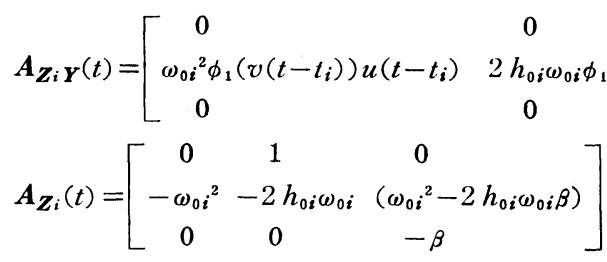

ここに, $u\left(t-t_{i}\right)$ は単位階段関数を表わすものとする. 次に外力ベクトルについて説明する. 不規則外力は, 一般に平均値の変化と平均值回りの変動に分離すること ができる.ここで, $N_{i}(t)$ は外力の平均值の変化であ り， $\boldsymbol{F}_{i}(t)$ は平均值回りの変動を表わしている. $\boldsymbol{N}_{\boldsymbol{i}}(t)$ による応答は, 従来の確定論的な手法で解析される. そ れぞれの外力による応答は重㸚合わせが 可能であるの で，本論文では， $\boldsymbol{F}_{i}(t)$ による応答解析の手法について 説明する. この $\boldsymbol{F}_{i}(t)$ の要素は, 次のように橋梁系と 連行車両一路面系のブロックに分割される.

$$
\boldsymbol{F}_{i}\left(t-t_{1 i}\right)=\left[\begin{array}{l}
\boldsymbol{F}_{\boldsymbol{Y}_{i}}(t) \\
\boldsymbol{F}_{\boldsymbol{Z}_{i}}(t)
\end{array}\right] w\left(t-t_{1 i}\right)
$$

ここに, $w\left(t-t_{1 i}\right)$ は 2. 式 (12), (13) で定義される白 色雑音過程である. ブロック $\boldsymbol{F}_{\boldsymbol{Y}_{\boldsymbol{i}}}(t)$ の要素は

$$
\boldsymbol{F}_{\boldsymbol{Y}_{i}}(t)=\left[0-2 h_{0 i} \omega_{0 i} R_{i 1} \phi_{1}\left(v\left(t-t_{i}\right)\right) u\left(t-t_{i}\right)\right]^{T}
$$

である.また, $\boldsymbol{F}_{\boldsymbol{Z}_{i}}(t)$ はさらに次のようなブロックに 分割できる.

$$
\boldsymbol{F}_{\boldsymbol{Z}_{i}}(t)=\left[\begin{array}{lll}
\boldsymbol{O}_{1 i-1} & \boldsymbol{F}_{\boldsymbol{Z}_{\boldsymbol{i} i}} & \mathbf{0}_{\boldsymbol{i + 1} \boldsymbol{n}}
\end{array}\right]^{T}
$$

ここに, $\boldsymbol{O}_{k l}$ は $k$ 台目から $l$ 台目の車両-路面系の外力 ベクトルが０であることを表わすものとする．また， $\boldsymbol{F}_{\boldsymbol{Z} i \boldsymbol{i}}(t)$ の要素は

$$
\boldsymbol{F}_{\boldsymbol{Z}_{i i}}=\left[\begin{array}{lll}
0 & -2 h_{0 i} \omega_{0 i} & 1
\end{array}\right]^{\boldsymbol{T}}
$$

である.

各車両には車頭間隔時間の遅れで，同一の凹凸が作用 する.式（19）また式（27）のような外力の表現は，各 車両が 同一路面上を 走行することを強調したものであ る. 上記のような橋梁-連行車両一路面系の記述を用いる と，この系の方程式は簡潔な形で 表現することができ る. すなわち, 車両台数の変化に対しては, 対応する行 列のブロックを増減するだけで，方程式の形を変化させ る必要はない，さらに，車両が道路上を走行する状態と 橋梁上を走行する状態は, 係数行列 $\boldsymbol{A}_{\boldsymbol{X}}(\boldsymbol{t})$ および外力 ベクトル $\boldsymbol{F}_{\boldsymbol{X}}(t)$ の所定の要素に，単位階段関数を掛け ることにより統一的に表現できる.

\section{4. 不規則応答解析の理論}

\section{（1）応答過程の確率特性}

路面凹凸を正規性過程でモデル化すると，その応答は
正規性過程となる．したがって，確率特性は平均値と分 散・共分散により規定される。平均值応答は，ほほ静的 応答に一致することが知られている ${ }^{11)}$. 一般性を失うこ となく, 応答は平均值と平均値回りの変動に分離できる ので以後,応答は平均值回りの変動を表わするのとする.

橋梁の変位および速度の分散・共分散応答は, 橋梁の 1 次振動のみを考えると，

$$
\begin{aligned}
& {\left[\begin{array}{cc}
\mathrm{E}\left[y(x, t)^{2}\right] & \mathrm{E}[y(x, t) \dot{y}(x, t)] \\
\mathrm{E}[\dot{y}(x, t) y(x, t)] & \mathrm{E}\left[\dot{y}(x, t)^{2}\right]
\end{array}\right]} \\
& =\phi_{1}(x) \boldsymbol{R}_{\boldsymbol{Y}}(t) \phi_{1}(x)
\end{aligned}
$$

で表わされる. ここに， $\boldsymbol{R}_{\boldsymbol{Y}}(t)$ は橋梁系の状態変数 $\boldsymbol{Y}(t)$ の共分散行列.

$$
\boldsymbol{R}_{\boldsymbol{Y}}(t)=\mathrm{E}\left[\boldsymbol{Y}(t) \boldsymbol{Y}(t)^{T}\right]
$$

である. $\boldsymbol{Y}(t)$ は橋梁-連行車両-路面系 $\boldsymbol{X}(t)$ の要素で あり，X(t) の時間的変化は式 (19) の確率微分方程式 で表わされている．なお，ここでは，平均值の変動 $N_{i}$ （ $t$ ）は考えていない. したがって，本解法は $\boldsymbol{X}(t)$ の共 分散

$$
\boldsymbol{R}_{\boldsymbol{X}}(t)=\mathrm{E}\left[\boldsymbol{X}(t) \boldsymbol{X}(t)^{T}\right]
$$

の解析に帰着する.

この解過程の確率特性は, 外力と初期条件の確率特性 に規定されている. 次に, これらの確率特性について簡 単に説明しておく. 外力 $\boldsymbol{F}_{i}\left(t-t_{1 i}\right)$ は式 (27) により, 次の確率特性を有する正規性白色雑音過程ベクトルであ る.

$$
\left.\begin{array}{ll}
\text { (i) } & \mathrm{E}\left[\boldsymbol{F}_{\boldsymbol{i}}(\tau)\right]=\mathbf{0} \\
\text { (ii) } \mathrm{E}\left[\boldsymbol{F}_{\boldsymbol{i}}\left(\tau_{1}\right) \boldsymbol{F}_{j}\left(\tau_{2}\right)^{T}\right]=\boldsymbol{Q}_{\boldsymbol{X}_{i j}}\left(\tau_{1}\right) \delta\left(\tau_{1}-\tau_{2}\right)
\end{array}\right\}
$$

$\boldsymbol{Q}_{\boldsymbol{X}_{i}}(t)$ は，橋梁系と 連行車両一路面系のブロックに分 割されて

$$
\begin{aligned}
& \boldsymbol{Q}_{\boldsymbol{X}_{i j}}(t)=\left[\begin{array}{cc}
\boldsymbol{Q}_{\boldsymbol{Y}_{i j}}(t) & \boldsymbol{Q}_{\boldsymbol{Y} \boldsymbol{Z}_{i j}}(t) \\
\boldsymbol{Q}_{\boldsymbol{Z} \boldsymbol{Y}_{i j}}(t) & \boldsymbol{Q}_{\boldsymbol{Z}_{i j}}(t)
\end{array}\right] \\
& =\left[\begin{array}{l}
\boldsymbol{F}_{\boldsymbol{Y}_{i}}\left(t+t_{1 i}\right) \cdot \boldsymbol{F}_{\boldsymbol{Y}_{j}}\left(t+t_{1 j}\right)^{T} \\
\boldsymbol{F}_{Z_{i}}\left(t+t_{1 i}\right) \cdot \boldsymbol{F}_{\boldsymbol{Y}_{j}}\left(t+t_{1 j}\right)^{T}
\end{array}\right. \\
& \left.\begin{array}{l}
\boldsymbol{F}_{\boldsymbol{Y}_{i}}\left(t+t_{1 i}\right) \cdot \boldsymbol{F}_{\boldsymbol{Z}_{j}}\left(t+t_{1 j}\right)^{T} \\
\boldsymbol{F}_{\boldsymbol{Z}_{i}}\left(t+t_{1 i}\right) \cdot \boldsymbol{F}_{\boldsymbol{Z}_{j}}\left(t+t_{1 j}\right)^{T}
\end{array}\right] \cdot S_{0}
\end{aligned}
$$

のように表わされる．また初期条件 $\boldsymbol{X}_{0}$ は，先頭の車両 が橋梁に進入する直前の橋梁-連行車両-路面系の状態変 数である. 路面凹凸が平均值 0 の正規性過程でモデル 化されているので, $x_{0}$ は平均値 0 , 共分散

$$
R_{0}=\mathrm{E}\left[X_{0} X_{0}^{T}\right] \text {. }
$$

を有する正規性確率変数となる.この詳細な取扱いは後 節で説明する. 


\section{（2）非定常応答解析}

$N_{i}(t)$ を除く確率微分方程式 (19) の解は, 線形微分 方程式の理論より

$$
\boldsymbol{X}(t)=\boldsymbol{\Phi}_{\boldsymbol{X}}\left(t, t_{1}\right) \boldsymbol{X}_{0}+\sum_{i=1}^{n} \int_{t_{1}}^{t} \boldsymbol{\Phi}(t, \tau) \boldsymbol{F}_{i}\left(\tau-t_{1 i}\right) d \tau
$$

となる.ここに, $\Phi_{\boldsymbol{X}}\left(t, t_{1}\right)$ は橋梁-連行車両-路面系

$$
\dot{\boldsymbol{X}}(t)=\boldsymbol{A}_{\boldsymbol{X}}(t) \boldsymbol{X}(t)
$$

の状態遷移行列である. この系は車両が次々に橋梁に進 入し通過するような不連続な系であるが， 3. で示した ように係数行列 $\boldsymbol{A}_{\boldsymbol{X}}(t)$ を単位階段関数を含む要素で構 成することにより，式の上では連続な系として取り扱う ことができる. 式 (37) において, 変数変換 $\tau-t_{1 i}=\tau^{\prime}$ を行い，改めて $\tau^{\prime} を \tau$ と置くと，式 (37) は

$$
\begin{aligned}
\boldsymbol{X}(t)= & \boldsymbol{\Phi}_{\boldsymbol{X}}\left(t, t_{1}\right) \boldsymbol{X}_{\mathbf{0}} \\
& +\sum_{i=1}^{n} \int_{t_{1-1} t_{i i}}^{t-t_{1 i}} \Phi_{\boldsymbol{X}}\left(t, \tau+t_{1 i}\right) \boldsymbol{F}_{i}(\tau) d \tau
\end{aligned}
$$

となる. この $\boldsymbol{X}(t)$ を式 (33) の共分散の定義式に代入 し， $\boldsymbol{F}_{i}(t)$ が白色雑音過程ベクトルであることを考庶し て積分を実行すると， $X(t)$ の共分散は

$$
\begin{aligned}
& \boldsymbol{R}_{\boldsymbol{X}}(t)=\boldsymbol{\Phi}_{\boldsymbol{X}}\left(t, t_{1}\right) \boldsymbol{R}_{X_{0}} \Phi_{\boldsymbol{X}}\left(t, t_{1}\right)^{T} \\
& +\sum_{i=1}^{n} \int_{t_{1}-t_{1 i}}^{t-t_{1 i}} \Phi_{X}\left(t, \tau+t_{1 i}\right) \mathrm{E}\left[\boldsymbol{F}_{i}(\tau)\right. \\
& \text { - } \left.\boldsymbol{X}_{0}^{T}\right] d \tau \Phi_{X}\left(t, t_{1}\right)^{T} \\
& +\Phi_{X}\left(t, t_{1}\right) \sum_{j=1}^{n} \int_{t_{1}-t_{1 j}}^{t-t_{1 j}} \\
& \mathrm{E}\left[\boldsymbol{X}_{0} \boldsymbol{F}_{j}(\tau)^{\boldsymbol{T}}\right] \boldsymbol{\Phi}_{\boldsymbol{X}}\left(t, \tau+t_{1 j}\right)^{\boldsymbol{T}} d \tau \\
& +\sum_{i=1}^{n} \sum_{j=1}^{n} \int_{\max \left(t_{1}-t_{1 i}, t_{1}-t_{1 j}\right)}^{\min \left(t-t_{1 i}, t-t_{1}\right)} \\
& \boldsymbol{\Phi}_{\boldsymbol{X}}\left(t, \tau+t_{1 i}\right) \boldsymbol{Q}_{\boldsymbol{X}_{i j}}(\tau) \boldsymbol{\Phi}_{\boldsymbol{X}}\left(t, \tau+t_{1 j}\right)^{T} d \tau
\end{aligned}
$$

で与えられる. ここに, $\max (a, b)$ および $\min (a, b)$ は，それぞれ $a$ および $b$ の最大または最小を表わすもの とする. 次に式 (40) の両辺を $t$ で微分し式の変形を行 うと, 次の共分散方程式を誘導することができる.

$$
\begin{aligned}
\dot{\boldsymbol{R}}_{\boldsymbol{X}}(t)= & \boldsymbol{A}_{\boldsymbol{X}}(t) \boldsymbol{R}_{\boldsymbol{X}}(t)+\boldsymbol{R}_{\boldsymbol{X}}(t) \boldsymbol{A}_{\boldsymbol{X}}(t)^{T} \\
& +\sum_{i=1}^{n} \mathrm{E}\left[\boldsymbol{F}_{i}\left(t-t_{1 i}\right) \boldsymbol{X}_{0}{ }^{T}\right] \\
& +\sum_{j=1}^{n} \mathrm{E}\left[\boldsymbol{X}_{0} \boldsymbol{F}_{j}\left(t-t_{1 j}\right)^{T}\right] \\
& +\sum_{i=1}^{n} \sum_{j=1}^{i} \boldsymbol{Q}_{\boldsymbol{X}_{i j}{ }^{\prime}\left(t-t_{j i}\right)} \\
& +\Phi_{\boldsymbol{X}}\left(t, t-t_{j i}\right)^{T} u\left(t-t_{1}-t_{j i}\right) \\
& +\sum_{i=1}^{n} \sum_{j=i}^{n} \boldsymbol{\Phi}_{\boldsymbol{X}}\left(t, t-t_{i j}\right) \\
& \times \boldsymbol{Q}_{\boldsymbol{X}_{i j}{ }^{\prime}\left(t-t_{i j}\right) u\left(t-t_{1}-t_{i j}\right)}
\end{aligned}
$$

ここに,

$$
\left.\begin{array}{rl}
\boldsymbol{Q}_{\boldsymbol{X}_{i j}{ }^{\prime}}(t) & =\boldsymbol{Q}_{\boldsymbol{X}_{i j}}(t) \quad(i \neq j) \\
& =\frac{1}{2} \boldsymbol{Q}_{\boldsymbol{X}_{i j}}(t) \quad(i=j)
\end{array}\right\}
$$

である.

しかし, この方程式では, 初期条件と外力の共分散 $\mathrm{E}\left[\boldsymbol{F}_{\boldsymbol{i}}\left(t-t_{1 i}\right) \boldsymbol{X}_{0}{ }^{T}\right]$ および $\mathrm{E}\left[\boldsymbol{X}_{0} \boldsymbol{F}_{j}\left(t-t_{1 j}\right)^{T}\right]$ が未知量 として残っている. これは, 次のような処理により得ら れる. 無限遠点より発進した車両は, 路面凹凸上を走行 し, 定常状態に達した後橋梁に進入するものとする. こ の場合, 橋梁-連行車両一路面系の初期条件は,

$$
\boldsymbol{X}_{0}=\sum_{j=1}^{n} \int_{-\infty}^{t} \boldsymbol{\Phi}_{\boldsymbol{X}}(t, \tau) \boldsymbol{F}_{j}\left(\tau-t_{1 j}\right) d \tau
$$

で与えられる. この式に $F_{i}\left(t-t_{1 i}\right)$ を掛けた後, 両辺 に平均操作を施し, 白色雑音過程の性質を用いて積分を 実行すると, 次式を得る.

$$
\begin{aligned}
\sum_{i=1}^{n} \mathrm{E} & {\left[\boldsymbol{F}_{\boldsymbol{i}}\left(t-t_{1 i}\right) \boldsymbol{X}_{0}{ }^{T}\right] } \\
= & \sum_{i=1}^{n} \sum_{j=1}^{i} \boldsymbol{Q}_{\boldsymbol{X}_{i j}{ }^{\prime}}\left(t-t_{j i}\right) \\
& . \boldsymbol{\Phi}_{\boldsymbol{X}}\left(t_{1}, t-t_{j i}\right)^{T}\left(1-u\left(t-t_{1}-t_{j i}\right)\right)
\end{aligned}
$$

$$
\begin{aligned}
\sum_{i=1}^{n} \mathrm{E} & {\left[\boldsymbol{X}_{0} \boldsymbol{F}_{i}\left(t-t_{1 i}\right)^{T}\right] } \\
=\sum_{i=1}^{n} \sum_{j=i}^{n} \boldsymbol{\Phi}_{\boldsymbol{X}}\left(t_{1}, t-t_{i j}\right) & \\
& \cdot \boldsymbol{Q}_{\boldsymbol{X}_{j i}{ }{ }{ }\left(t-t_{i j}\right)\left(1-u\left(t-t_{1}-t_{i j}\right)\right)}
\end{aligned}
$$

$n$ 台の車両が橋梁に進入し, 通過する状態を統一的に表 現する共分散方程式は, 式 (41)，(44)，(45) より

$$
\begin{aligned}
\dot{\boldsymbol{R}}_{\boldsymbol{X}}(t)= & \boldsymbol{A}_{\boldsymbol{X}}(t) \boldsymbol{R}_{\boldsymbol{X}}(t)+\boldsymbol{R}_{\boldsymbol{X}}(t) \boldsymbol{A}_{\boldsymbol{X}}{ }^{(t)}{ }^{T} \\
& +\sum_{i=1}^{n} \sum_{j=1}^{i} \boldsymbol{Q}_{\boldsymbol{X}_{i j}{ }^{\prime}\left(t-t_{j i}\right) \boldsymbol{\Phi}_{\boldsymbol{X}}\left(t, t-t_{j i}\right)^{T}} \\
& +\sum_{i=1}^{n} \sum_{j=i}^{n} \boldsymbol{\Phi}_{\boldsymbol{X}}\left(t, t-t_{i j}\right) \boldsymbol{Q}_{\boldsymbol{X}_{i j}{ }^{\prime}\left(t-t_{i j}\right)}
\end{aligned}
$$

$$
\boldsymbol{R}_{\boldsymbol{X}}\left(t_{1}\right)=\boldsymbol{R}_{\boldsymbol{X}}
$$

となる. この共分散方程式は, 車両と橋梁の連成, 橋梁 を介する車両間の連成および車両間の相関を厳密に評価 したものである. 右辺第 3 項と第 4 項の $i \neq j$ の項は 車両間の相関を表わす項である. 小松・川谷が文献 17) で用いた共振車頭間隔は，不規則振動論で表現するとこ の項に関係している.

ところで,この車両間の相関を無視すると，1 1 つ近 似解法が得られる。

$$
\begin{aligned}
& \dot{\boldsymbol{R}}_{\boldsymbol{X}}(t)=\boldsymbol{A}_{\boldsymbol{X}}(t) \boldsymbol{R}_{\boldsymbol{X}}(t)+\boldsymbol{R}_{\boldsymbol{X}}(t) \boldsymbol{A}_{\boldsymbol{X}}(t) \\
& +\sum_{i=1}^{n} \boldsymbol{Q}_{X_{i i}}\left(t-t_{1 i}\right) \\
& \boldsymbol{R}_{\boldsymbol{X}}\left(t_{1}\right)=\boldsymbol{R}_{\boldsymbol{X}_{0}}
\end{aligned}
$$

この方程式は車両間の相関を 0 としただけで, 車両間の 連成は考慮されている. 式（46）と比べて状態遷移行列 
岡林・山口：

の計算が必要ないので, 計算時間の短縮が図れる. 以 後, この方程式を車両間の相関を無視した共分散方程式 と称することにする.

\section{（3）初期条件の処理}

前項の共分散方程式の初期条件は, 橋梁-連行車両一路 面系の初期条件 $\boldsymbol{X}_{0}$ の共分散 $\boldsymbol{R}_{\boldsymbol{X}}$ 。である.この初期条 件 $\boldsymbol{R}_{\boldsymbol{X}_{0}}$ の誘導について説明する.

無限遠点より発進し, 不規則路面凹凸上を走行する $n$ 台の連行車両について考える. 車両は道路上を走行し橋 梁に達していないが，橋梁の変数も含んだ形で 処理す る. $\infty \leq t \leq t_{1}$ において応答は定常過程

$$
\boldsymbol{X}(t)=\sum_{i=1}^{n} \int_{-\infty}^{t} \boldsymbol{\Phi}(t, \tau) \boldsymbol{F}_{i}\left(\tau-t_{1 i}\right) d \tau
$$

で表わされる. $\boldsymbol{X}(t)$ の共分散は,

$$
\begin{aligned}
\boldsymbol{R}_{\boldsymbol{X}}(t)= & \sum_{i=1}^{n} \sum_{j=1}^{n} \int_{-\infty}^{\min \left(t-t_{1 i}, t-t_{1 j}\right)} \\
& \times \boldsymbol{\Phi}_{\boldsymbol{X}}\left(t, \tau+t_{1 i}\right) \boldsymbol{Q}_{\boldsymbol{X}_{i j}}(\tau) \boldsymbol{\Phi}_{\boldsymbol{X}^{(}}\left(t, \tau+t_{i j}\right)^{T} d \tau
\end{aligned}
$$

となる.この式は式 (46) と同形の共分散方程式に変換 できる，しかし，路面上を走行する車両では，係数行列 $\boldsymbol{A}_{\boldsymbol{X}}(t)$ と外力の共分散行列 $\boldsymbol{Q}_{\boldsymbol{X}}{ }_{i j}(t)$ はそれぞれ 定数行 列となる.これらをそれぞれ $\boldsymbol{A}_{\boldsymbol{X}}$ および $\boldsymbol{Q}_{\boldsymbol{X}_{i j}}$ で表わ す.したがって, この系は定数係数系となり, 状態遷移 行列は時間差の関数

$$
\boldsymbol{\Phi}_{\boldsymbol{X}}\left(t, t-t_{i j}\right)=\boldsymbol{\Phi}_{\boldsymbol{X}}\left(t_{i j}\right)
$$

となる.さらに, 初期条件が無視できる時間経過後の応 答を考えているので, 応答の共分散の時間微分 $\dot{\boldsymbol{R}}_{\boldsymbol{X}}(t)$ は 0 となる. ゆえに, 次の共分散方程式を得る.

$$
\begin{aligned}
& \boldsymbol{A}_{\boldsymbol{X}} \boldsymbol{R}_{X_{0}}+\boldsymbol{R}_{X_{0}} \boldsymbol{A}_{X^{T}}+\sum_{i=1}^{n} \sum_{j=1}^{i} \boldsymbol{Q}_{X_{i j}}{ }^{\prime} \Phi_{X^{(}\left(t_{i j}\right)^{T}} \\
& \sum_{i=1}^{n} \sum_{j=i}^{n} \Phi_{\boldsymbol{X}}\left(t_{j i}\right) \boldsymbol{Q}_{\boldsymbol{X}_{i j}{ }^{\prime}}=\mathbf{0}
\end{aligned}
$$

ここで, $\boldsymbol{R}_{\boldsymbol{X} \mathbf{0}}$ の要素について考える. これは, 次のよ うなブロックに分割される.

$$
\boldsymbol{R}_{\boldsymbol{X}_{0}}=\left[\begin{array}{cc}
\boldsymbol{R}_{\boldsymbol{Y}_{0}} & \boldsymbol{R}_{\boldsymbol{Y}_{0} \boldsymbol{Z}_{0}} \\
\boldsymbol{R}_{\boldsymbol{Z}_{0} \boldsymbol{Y}_{0}} & \boldsymbol{R}_{\boldsymbol{Z}_{0}}
\end{array}\right]
$$

車网が進人するまで橋梁は静止しているので，橋梁の変 数を含む共分散 $R_{Y_{0}}, R_{Y_{0} Z_{0}}$ および $R_{Z_{0} Y_{0}}$ はすべて 0 となる，最後の $\boldsymbol{R}_{\boldsymbol{Z}_{0}}$ を $(i, j)$ ブロックの行列

$$
\boldsymbol{R}_{\boldsymbol{Z}_{0}}=\left\lfloor\boldsymbol{R}_{\boldsymbol{Z}_{0 i j}}\right\rfloor
$$

上り構成するおのとすると，各ブロックの行列 $\boldsymbol{R}_{\boldsymbol{Z}_{0 i}}$, および $\boldsymbol{R}_{\boldsymbol{Z}_{0 i j}}$ 仗次式より得られる.

$$
\begin{aligned}
& \boldsymbol{A}_{\boldsymbol{Z}_{i}} \boldsymbol{R}_{\boldsymbol{Z}_{0 i}+} \cdot \boldsymbol{R}_{\boldsymbol{Z}_{0 i}} \boldsymbol{A}_{\boldsymbol{Z}_{i}}{ }^{\mathrm{T}}+\boldsymbol{Q}_{\boldsymbol{F}_{i} i}=\mathbf{0} \\
& \left.\begin{array}{c}
\boldsymbol{A}_{Z_{i}} \boldsymbol{R}_{Z_{0 i j}}+\boldsymbol{R}_{Z_{0} i j} \boldsymbol{A}_{\left.Z_{j}{ }^{T}+\Phi_{Z_{i}\left(t_{i j}\right.}\right) \boldsymbol{Q}_{\boldsymbol{F}_{i j}}} \\
+\boldsymbol{Q}_{\boldsymbol{F}_{i j} \Phi_{Z_{i}}\left(t_{i j}\right)^{T}=\mathbf{0}}
\end{array}\right\}
\end{aligned}
$$

ここに， $\boldsymbol{Q}_{\boldsymbol{F}_{i j}}$ は式 (30) の $\boldsymbol{F}_{i i}(\boldsymbol{t})$ を用いて

$$
\boldsymbol{Q}_{\boldsymbol{F}_{i j}}=\boldsymbol{F}_{i i}(t) \boldsymbol{F}_{j j}(t)^{T}
$$

で表わされる.

\section{（4）定常応答解析}

路面凹凸上を走行する車両の接地力が常に橋梁の定位 置に作用するものと仮定すると, 初期条件および車両の 走行により生ずる非定常性を無視した, 定常応答解析が 可能になる. 単一走行車両による橋梁の応答解析では, 定常応答解析は非定常応答解析による最大応答を推定す る近似解法として有効であった ${ }^{5), 6)}$. 連行車両による応 答に対しても，定常応答解析の 有效性について 検討す る.

車両を定位置に固定すると, 橋梁-連行車両一路面系の 方程式の時変係数は,

$$
\phi_{1}\left(v\left(t-t_{i}\right)\right)=\phi_{1}\left(\lambda_{i}\right)
$$

のように橋端から作用する車両までの距離 $\lambda_{i}$ の関数と なる. この系の状態遷移行列は, 初期時刻に関係のない $i$ 台目の車両と $j$ 台目の 車両の車頭間隔時間 $t_{i j}$, すな わち車頭間隔 $\lambda_{i j}$ の関数

$$
\Phi_{\boldsymbol{X}}\left(t, t-t_{i j}\right)=\Phi_{\boldsymbol{X}}\left(t_{i j}\right)=\Phi\left(\lambda_{i j}\right)
$$

となる. このような仮定のもとで，共分散方程式 (46) の係数行列 $\boldsymbol{A}_{\boldsymbol{X}}(t)$, 外力の共分散行列 $\boldsymbol{Q}_{\boldsymbol{X}_{i j}}(t)$ さらに 状態遷移行列 $\Phi_{\boldsymbol{X}}\left(t, t-t_{i j}\right)$ はそれぞれ 定数行列 とな る. 対応する行列を $\boldsymbol{A}_{\boldsymbol{X}}, \boldsymbol{Q}_{\boldsymbol{X} i j}$ および $\boldsymbol{\Phi}_{\boldsymbol{X}}\left(t_{i j}\right)$ で表わ す. したがって, $t \rightarrow \infty$ では応答は定常応答になる. 定常状態では, 式 (46) の共分散方程式は連立方程式

$$
\begin{aligned}
\boldsymbol{A}_{\boldsymbol{X}} \boldsymbol{R}_{\boldsymbol{X}} & +\boldsymbol{R}_{\boldsymbol{X}} \boldsymbol{A}_{\boldsymbol{X}}{ }^{T}+\sum_{i=1}^{n} \sum_{j=1}^{i} \boldsymbol{Q}_{\boldsymbol{X}_{i j}{ }^{\prime}} \boldsymbol{\Phi}_{\boldsymbol{X}}\left(t_{i j}\right) \\
& +\sum_{i=1}^{n} \sum_{j=i}^{n} \boldsymbol{\Phi}_{\boldsymbol{X}}\left(t_{i j}\right) \boldsymbol{Q}_{\boldsymbol{X}_{i j}{ }^{\prime}}=\mathbf{0} \ldots \ldots \ldots
\end{aligned}
$$

で表わされる. なお， $\boldsymbol{R}_{\boldsymbol{X}}$ は $\boldsymbol{R}_{\boldsymbol{X}}(t)$ の定常解を示すも のとする.

一方, 非定常応答解析と同様に, 車両間の相関を無視 した解法

$$
\boldsymbol{A}_{\boldsymbol{X}} \boldsymbol{R}_{\boldsymbol{X}}+\boldsymbol{R}_{\boldsymbol{X}} \boldsymbol{A}_{\boldsymbol{X}}{ }^{T}+\sum_{i=1}^{n} \boldsymbol{Q}_{X_{i i}}=\mathbf{0}
$$

が提案できる.これを, 以後車両間の相関を無視した定 常応答解析と称する. この方程式において, 車両の振動 が互いに独立であるといら仮定を導人する.すなわち, 車両間の連成に関する項, $\boldsymbol{A}_{\boldsymbol{X}}$ における $\boldsymbol{A}_{\boldsymbol{Z} \boldsymbol{Y}}$ を無視し た場合, この解法は山田・小堀による文献 1）の解法と 一致する.

\section{5. 連行車両のモデルと橋梁の諸元}

実際の橋梁では支間長が长くなると，大型車が同時に 載荷する可能性が大きくなり, 単一車両だけで道路橋の 状態を推定することは不十分である. さらに，現実の状 況を反映させるためには, 車種, 走行速度および車頭間 


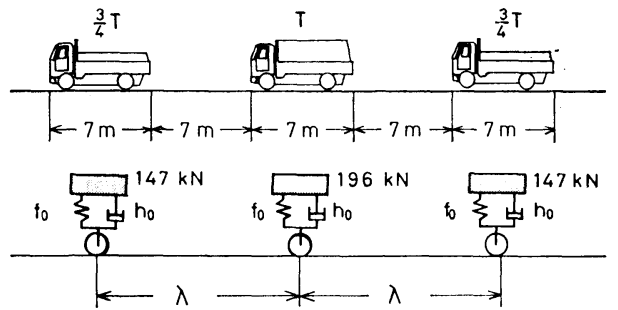

図一3 連行車両列荷重の解析モデル

隔を不確定変量とする取扱いが必要となる．ところで， 走行車両を連行車両でモデル化すると, 単一走行車両に よる応答では存在しなかった各種の干涉すなわち, 車両 間の連成および車両間の相関が発生する.この効果によ って, 連行車両の走行する橋梁は単一走行車両による場 合と異なった振動性状を呈する. したがって，各種のパ ラメーターを確率変量として解析する前に，まず連行車 両による応答を支配する主要なパラメーターを選び，そ のパラメーターが応答に及ぼす影響について検討する必 要がある. このような観点から, 以下のような諸元の車 両および橋梁を対象にした数值計算を行った.

道路橋示方書 ${ }^{25}$ によれば，一等橋の設計活荷重である $L-20$ は，図一3 のような自動車列荷重を想定したもの である. 本論文では, この連行車両を図一3の下図のよ うに各車両を 1 自由度系で表現した車両列荷重によりモ デル化する. 数值計算では, 車両は大型車に限定し, 車 種の変動は考えない. さらに，車頭間隔入は確定量とす る. 大型車の動特性の実測は小松・川谷によるものがあ る. 彦坂ら ${ }^{19}$ はこれまでの実測結果を要約している. 本

\section{表 -1 走行車両の諸元}

\begin{tabular}{lr|ll}
\hline 総 重 量 & $w$ & 196,147 & $(\mathrm{kN})$ \\
ば㫟定 数 & $k$ & 7105,5329 & $(\mathrm{kN} / \mathrm{m})$ \\
固有振動数 & $f$ & 3.0 & $(\mathrm{~Hz})$ \\
減衰定 数 & $h$ & 0.03 & \\
走行速度 & $v$ & 10.0 & $(\mathrm{~m} / \mathrm{s})$ \\
\hline
\end{tabular}

論文で用いた車両の 諸元は、これらの平 均的な值を用いた. これを示したものが 表一1である. 車両 の動特性として, 車
両重量が異なる場合でも, 車両の固有振動数は同一であ るものとした. さらに, 進行速度は $v=10(\mathrm{~m} / \mathrm{s})$ で一定 であるものとする.

次に，道路橋の諸元について述べる，道路橋の支間长 上諸元は，文献 1) より引用した表一2を用いる。これ は, 建設省土木研究所設計合成析橋標準設計書より概算

表一2 道路橋の支間長と諸元

\begin{tabular}{|c|c|c|c|}
\hline $\begin{array}{c}\text { スハン展 } \\
\text { I (m) }\end{array}$ & 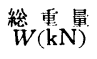 & $\begin{array}{l}\text { 曲!) 㓮性 } \\
E I(\mathrm{GN} \cdot \mathrm{m})\end{array}$ & $\begin{array}{c}\text { 周有掁動数 } \\
f(\mathbf{H z})\end{array}$ \\
\hline 20 & 474.3 & 6.085 & 6.23 \\
\hline 30 & 760.4 & 12.171 & 3.97 \\
\hline 40 & 1046.6 & 23.921 & 2.94 \\
\hline 50 & 1332.8 & 47.236 & 2.45 \\
\hline 60 & 1520.9 & 64.464 & 2.11 \\
\hline 70 & 1905.1 & 78.547 & 1.70 \\
\hline
\end{tabular}

したものである.

\section{（1）車両台数による影響}

連行車両列荷重をモデル化する場合，走行車両の状態 を規定する基本的なパラメーターは車両台数と車頭間隔 である. 車两台数と車頭間隔が橋梁の応答に及ぼす影響 を検討することにより，単一走行車両と異なった連行車 両による固有の応答性状を説明することができる.ここ では車両台数の忘答に及ぼす影響について検討した.

車両間の相関を考慮した解法に基づき，車両を 1 台， 2 台, 3 台と載荷させた場合について, 支間長 $L=50$ (m) の橋梁の解析を行った. 図一4 に, スパン中点の r.m.s. 変位応答を図示した. 図の横軸は, 先頭の車両が 橋梁に進入した後の経過時間を，先頭の車両が橋梁を通 過する時間 $T$ で無次元化した時間である. したがって， 先頭の車両が橋梁を通過した後では, $t / T$ の值は $t / T>$ 1 となる. 以後非定常応答解析ではこのような座標を用 いる. 図中の (A) および (B) は, それぞれ車頭間隔 $\lambda=14(\mathrm{~m})$ および $\lambda=16(\mathrm{~m})$ の計算結果である.これら の図で, 実線は 1 台載荷, 破線は 2 台載荷および 1 点鎖 線は 3 台載荷による応答である. $\lambda=14(\mathrm{~m})$ では車両台 数を増加させても応答には顕著な増加は認められない. しかも， 3 台載荷では，先頭の車両が通過する時刻で 1 台載荷より応答は小さくなっている. $\lambda=16(\mathrm{~m})$ では, 車両台数の増加に伴って最大応答は増加している.この ように載荷台数と応答の間には明確な対応関係は認めら れない. そこで, 車両台数の影響のみを抽出するため に，車両間の相関を無視した解析を試みた. 図一5 は $\lambda$ $=16(\mathrm{~m})$ の場合の結果である. 載荷台数を増加させて
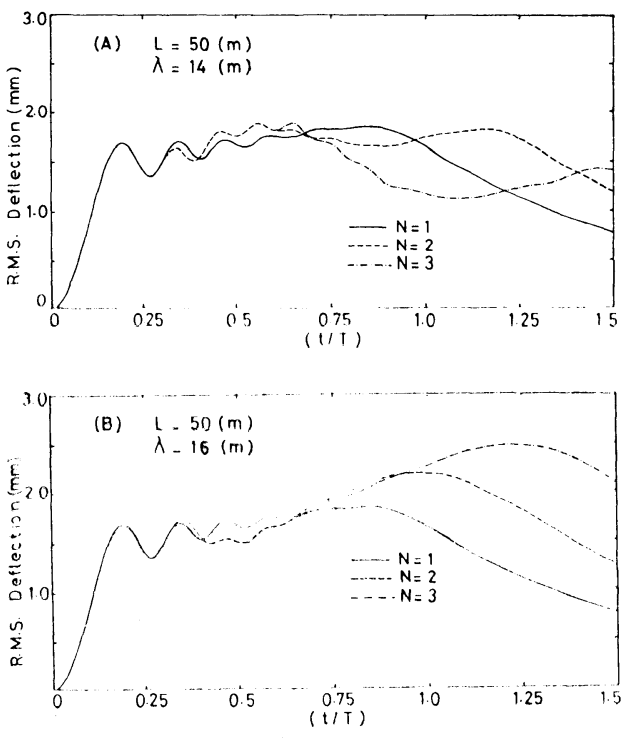

図-4 車両台数による r.m.s. 変位応答の変化 
岡林・山口：

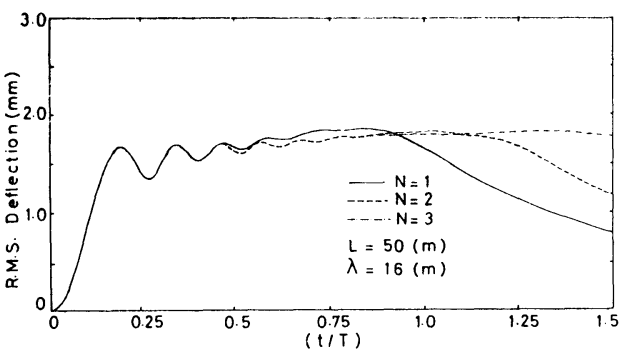

図一5車両間の相関を無視した応答

（車両台数による変化）

も最大応答は変化しないし, 応答形状にも差異は認めら れない，以上の結果より，車両間の相関を考えない限り 車両台数を増加させても応答は増加しないことがわか る. すなわち，単一走行車両による応答解析において指 摘したが，橋梁と車両の連成効果は振動を抑止するよう に作用する．連行車両による応答では，さらに各車両間 の連成が加わり，さらに橋梁の振動を抑止するものと考 えられる.

\section{（2）車頭間隔による影脾}

3 台の車両を 走行させた場合, 異なる車頭間隔 $\lambda$ に 対する応答を 図一6 に示した. 実線は $\lambda=14(\mathrm{~m})$, 破線 は $\lambda=15(\mathrm{~m})$ および 1 点鎖線は $\lambda=16(\mathrm{~m})$ とした場合 の応答を表わしている. なお，支間長 $L=50(\mathrm{~m})$ の場 合は， $\lambda=15(\mathrm{~m})$ と $\lambda=16(\mathrm{~m})$ の応答曲線が接近するの で, $\lambda=15(\mathrm{~m})$ の代わりに $\lambda=14.75(\mathrm{~m})$ で計算し，そ れを破線で表わした．また図中の（A)，(B) は，それぞ れ支間長 $L=50(\mathrm{~m})$ および $70(\mathrm{~m})$ の解析結果である.

図 (A) では車頭間隔を $14,14.75$ ，および $16(\mathrm{~m})$ と
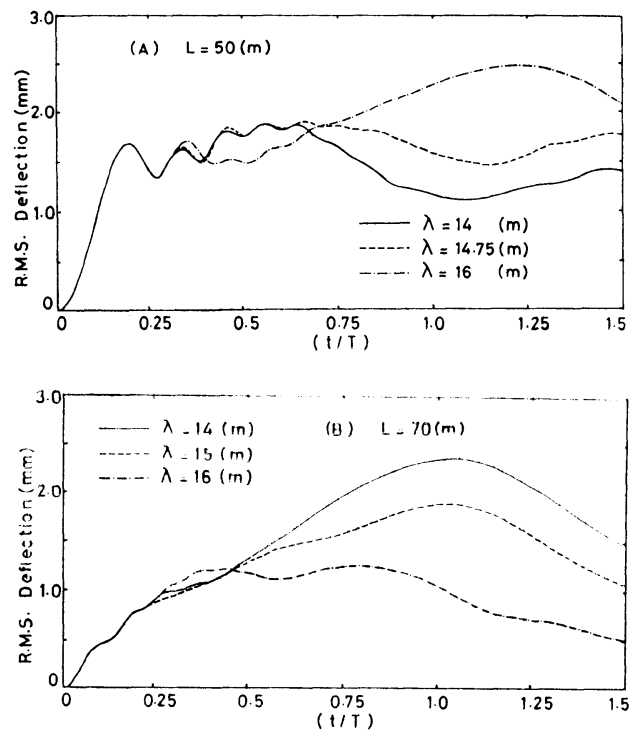

图一6 車頭間隔による r.m.s. 变位応答の変化
増加させると, 最大応答は順次増大する. 共分散方程式 （46）において，右辺第 3 項と 4 項 の $i=j$ 以外の外力 による橋梁の変位応答の值によって，車両間の相関を評 価するものとする. 橋梁-車両系は時変係数系であるの で車両閒の相関は各時刻において変化する.したがっ て，厳密な表現ではないが $L=50(\mathrm{~m})$ の場合， $\lambda=14$ (m) では車両間の相関は負となり， $\lambda=14.75(\mathrm{~m})$ では 相関はほぼ 0 ，さらに $\lambda=16(\mathrm{~m})$ では正と考えることに より，車頭間隔と忘答の関係が説明できる. $L=50(\mathrm{~m})$ の解析例のように，車両と固有振動数が接近する支間長 の橋梁の応答では，強い非定常効果のために 1 台目の車 両が進入した直後にピークを生じ，この点が最大応答に なる場合が多い，しかし，車頭間隔によっては，1台目 の車両が通過した後，このピークを越えて最大応答を示 す場合がある. 一方, 車両と橋梁の固有振動数が離れた $L=70(\mathrm{~m})$ の場合, 支間長が長くなると, 応答の挙動は 定常応答の挙動に近くなり，車両間の相関が応答に及ぼ す影響も大きくなる. $\lambda=14(\mathrm{~m})$ と $\lambda=16(\mathrm{~m})$ の最大応 答では，約 2 倍の差が生じる．なお， $\lambda=14(\mathrm{~m})$ の最大 応答は，単一車両による最大応答より小さな値となる. 図一7 は $L=50(\mathrm{~m})$ の場合，車両間の相関を 無視した 解析により，車頭間隔を変化させた応答を示したもので ある. 車頭間隔によって応答はほとんど変化しない，こ の最大応答は単一車両によるものと一致し，応答形状も 先頭車両が (3/4) $L$ に至るまでは，単一車両によるそ れとほぼ一致する.

以上，連行車両による橋梁の振動性状について検討し たが，連行車両による固有の振動性状は，車両間の連成 および車両間の相関による効果より説明できる. 車両台 数は, 車両間の連成の効果により橋梁の振動を抑止する ように作用する．また，車頭間隔は車両間の相関に直接 関係し，相関の值に対応して応答は増减する。

\section{（3） 定常応答解析による最大応答の推定}

最大 r.m.s. 応答は，応答を評価する 重要な指標であ る.この最大 r.m.s. 応答は非定常応答解析により厳密 に評価されるが，大次元の微分方程式を数値解析するこ

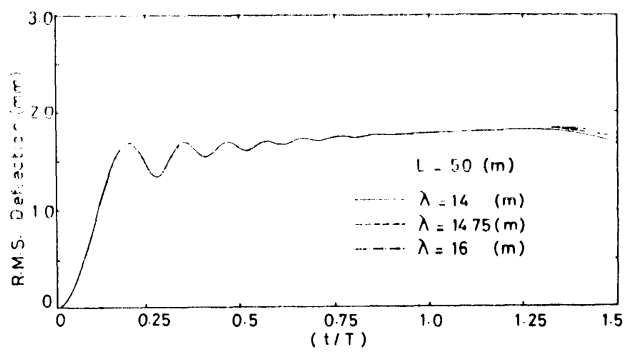

図-7 車両間の相関を無視した応答 （車頭間隔による変化） 

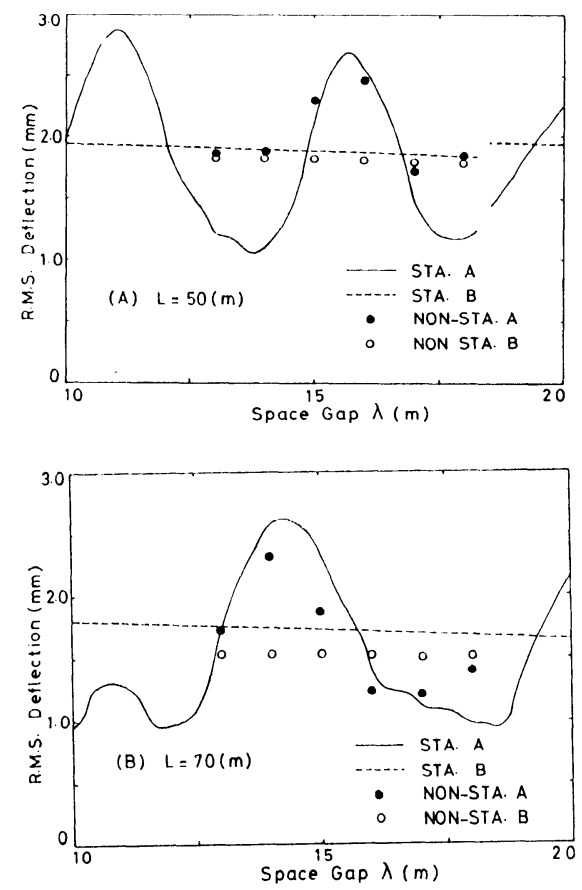

図一8最大および定常 r.m.s. 変位応答の車頭間隔 による変化

とになる. そこで, 単一走行車両による解析で提案し た, 定常応答解析による最大 r.m.s. 応答の推定を試み る.

図一8は，車頭間隔入をパラメーターにして橋梁支間 中点の最大 r.m.s. 変位応答と定常 r.m.s. 変位応答を図 示したものである. 図中の (A), (B) は, それぞれ $L=$ $50(\mathrm{~m})$ および $L=70(\mathrm{~m})$ の結果である. 図の横軸は, 変化させた車頭間隔 $\lambda=10 \sim 20(\mathrm{~m})$ を表わしている. 図 中の○は相関を考慮した非定常応答解析による最大 r.m.s. 変位応答, ○は相関を無視した場合の最大 r.m. s. 変位応答である. なお, 非定常解析では, 車頭間隔 を $13(\mathrm{~m})$ より $18(\mathrm{~m})$ まで $1(\mathrm{~m})$ 間隔で変化させた. また, 図中の実線は相関を考虑した定常応答, 破線は相 関を無視した定常応答である. 定常応答解析では, 車両 の載荷位置を次のように考えた. 車両は最大 3 台まで載 荷させ, 静的たわみが最大となる位置に載荷するものと する. 静的たわみが最大となる位置が, 必ずしも動的た わみが最大となるとは限らないので, 載荷台数が 3 台か ら 2 台に変わる所で, 定常応答の曲線は不連続になって いる.

図一8 $(\mathrm{A})$ すなわち $L=50(\mathrm{~m})$ の非定常応答解析にお いて, 車両間の相関を無視した解析では, 車頭間隔によ って最大 r.m.s. 応答はほとんど変化しない. 車両間の 相関を考慮した解析では，図一6で示したように，先頭 の車両が通過する近傍の応答が初期のピークを越えた場
合, この值が最大応答となる. しかし、この応答が初期 のピークを越えない場合は, 初期のピークが最大応答と なる.すなわち，車両間の相関が正と考えられる車頭間 隔では，相関を考慮した最大応答がこれを無視した最大 応答より大きくなる．相関が負と考えられる車頭間隔で は, 両最大応答は一致する. 次に, 定常応答解析では, 東両間の相関を無視した場合，車頭間隔による応答の変 化は少ない。しかし，相関を考虑した解析では，この応 答は車頭閒隔の増加に伴って, 相関を無視した応答の回 りを変動する.これは, 車頭間隔によって車両間の相関 が正と負の閒で変化するためであると考えられる.

$L=70(\mathrm{~m})$ すなわち図 (B) の場合, 車両間の相関を 無視した非定常応答解析では, 最大応答は車頭間隔の変 化に対してほぼ一定である.しかし，相関を考虑した最 大応答は, $L=50(\mathrm{~m})$ の場合と異なり, 相関を無視した 最大応答の回りを変動する. これは, 橋梁と車両の固有 振動数が離れると，図一6(B) に示したように非定常性 が緩やかになり， $L=50(\mathrm{~m})$ の場合に現われる初期のピ 一クが消失するためである.すなわち，この応答は定常 応答に近い挙動を示すことになる. 一方, 定常応答解析 による車両間の相関考慮および 無視による解析の結果 は, $L=50(\mathrm{~m})$ の結果とほぼ同じ傾向を示している.

上述のような傾向を確認したうえで，連行車両による 応答においても定常応答による最大応答の推定は可能で ある. 特に, 車両間の相関を無視した解析においては, 非定常応答の最大応答と定常応答の関係は単一走行車両 による応答と同じ傾向 ${ }^{5}$ を示し，定常応答解析は有効な 推定法と考えることができる.

\section{（4）衝撃係数の算定}

本解法を用いて衝撃係数の算定を行う.衝撃係数は彦 坂らが文献 19）で示した定義に従う.すなわち，非定 常応答解析の場合は,

$$
i=\frac{2 \sigma\left(l / 2, t_{s}\right)}{y_{s, \max }}
$$

である.ここに, $y_{s, \max }$ は静的たわみの最大值， $\sigma(l / 2$, $t_{s}$ ）は静的たわみが最大になる点に車両が到達したとき の支間中点の動的たわみの標準偏差である. 一方, 定常 応答解析による $\sigma\left(l / 2, t_{s}\right)$ は, 静的たわみが最大となる 車両位置に車両の接地力を作用させた場合, 支間中点の 応答を表わしている.

図一9 は，支間長 $L=50(\mathrm{~m})$ の橋梁を例にとり，車 頭間隔による衝撃係数の変化を図示したものである. 縦 軸は式（60）で算定した衝撃係数であり，横軸は車頭間 隔入である.なお，図中の表記は図一7に準じている． $\lambda=(3 / 8) \cdot L$ 近傍の曲線の不連続は, 前節でも述べた ように $\lambda<(3 / 8) \cdot L$ では 3 台の載荷台数を考え, $\lambda>$ 


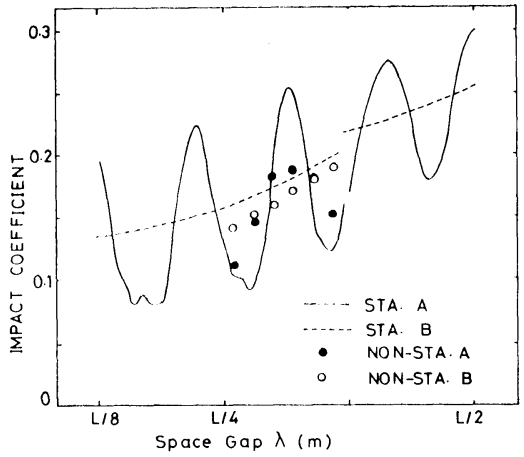

図-9 衝撃係数の車頭間隔による変動 $(L=50 \mathrm{~m})$

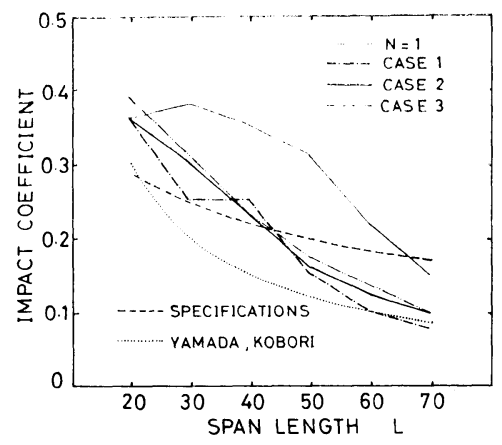

図-10 支間長と衛望係数

$(3 / 8) \cdot L$ では 2 台を考えているために生じる. 非定常お よび定常解析いずれによる場合でも車両間の相関を考慮 した衝撃係数は，車頭間隔の変化に伴って相関を無視し た衝撃係数の回りを変動する.したがって，車頭間隔に 関する衝撃係数の平均的な挙動は, 相関を無視した解析 より近似的に評価できるものと考えられる.

図一10 は支間長に対する衝撃係数を図示したもので ある. CASE-1，CASE-2 はそれぞれ車両間の相関を考 虑および 無視した非定常応答解析，CASE-3 は相関を 無視した定常応答解析より算定した衝撃係数である.な お，この図では，連行車両の車頭間隔は $14(\mathrm{~m})$ に固定 した. また， $N=1$ は，単一車両による非定常応答解析 より算定した衝撃係数である．さらに，破線は現行道路 橋示方書による衝撃倸数であり，点線は山田・小堀によ り文献 1）で提案されたものである，図のように，単一 走行車両による算定では明らかに過大な評価を与えるこ とになる. CASE-1 は車両と橋梁の固有振動数の関倸 により，支間長に対して変動する. CASE-2 と CASE3 はよい一致を示し，車両間の相関を無視した定常灾答 解析に基ついた衝撃係数の算定が可能なことを示してい る. そこで, CASE-3 と現行示方書の衝撃係数を比較 すると，現行示方書は $L<40(\mathrm{~m})$ では過小評価とな り， $L>40(\mathrm{~m})$ では 過大評価となっている. 文献 1) の衝撃係数と 比較すると， $L<70(\mathrm{~m})$ までこの衝撃係
数は本解法のそれより小さな値となっている. $L=70$ (m) 近傍では両者は一致する. 文献 1) の解析は, 本 解法と 解析条件の仮定と車両の載荷条件が 異なってい る. 寸なわち, 解析の仮定として, 各車両の振動が独立 であるとして車両間の連成を考慮していない，また，載 荷条件は $10(\mathrm{~m})$ の間隔で 20(t) の車両を載荷してい る. 本解法によれば, 支閒長が長くなると車両台数の上 限を 3 台と考えても, 图のように衝撃係数は急激に減少 する.この理由は，(2),(3) で考察したように，車両間 の連成効果により車両台数が増加しても橋梁の応答は単 一車両の応答程度に抑止されるためであると考えられ る.なお，ここでは良好な路面状態のデータを用いてお り, 解析結果と示方書の比較には, さらに検討の余地が 残されている.

以上のように，本両列荷重のモデルにより衝撃係数は 変動寸る. 今後, 衝慗係数の算定のために, 実際の交通 流をモデル化した標準的な車雨列荷重のモデル化の作成 が望まれる。

\section{6. むす び}

本論文では，不規則路面凹凸上を走行する連行車両に よる, 非定常性, 各種の連成および車両間の相関をでき るだけ厳密に評価した二乗平均応答の解析手法を提示す るとともに，いくつかの近似解法を提案した. さらに, 本解法を単純桁橋に適用し 数值計算を行らことによっ て，いくつかの知見を得ることができた，得られた結果 を要約すると以下のようである.

（1）路面凹凹を白色雑音過程を入力とするフィルタ 一系でモデル化すると, 橋梁-連行車両-路面系は伊藤型 の確率微分方程式で記述できる. この方程式に基づい て, 連行車両による橋梁応答の分散・共分散を支配する 共分散方程式を誘導することができた.この方程式で は，非定常性，車両間の連成さらには相関を厳密に評価 することができる．本解法では，車両間の連成および相 関を無視した解析が可能であるばかりでなく，定常応答 理論による近似解法も統一的に取り扱うことができる.

（2）単純桁橋に対する数值解析より，連行車両によ る橋梁の振動を規定する主要なパラメーターについて検 討した. 車雨台数は, 連成の効果により橋梁の振動を抑 止するように作用する。，一方，車頭間隔は車両閒の相関 に直接関係する.すなわち，車頭間隔によっては車両台 数の増加に伴って橋梁の応答は増加する場合もあるが, 逆に単一車両による応答より小さくなる場合もある。

（3）共振車頭間隔は車両間の相関に関係しているこ とを示し, その定式化を行った. しかし, 支間長の短い 橋梁では強い非定常性のために共振車頭間隔を決定する 


\section{ことは困難である}

（4）非定常応答の最大态答を推定するために, 定常 応答解析に基づく簡便法を提案するとともに，その妥当 性の検討を行った.この解法では, 車両間の相関を考慮 した場合, 非定常性の弱い $L=60(\mathrm{~m})$ 以上の支間長に 対して, また車両間の相関を無視した場命, いずれの支 間長に対してもよい推定值を示す.

（5）本解法に基づいて衝撃係数の算定を行った. 車 两間の相関を考慮した解析では，車頭間隔を変化させる と衝撃係数は変動する. 車頭閒隔が一様に分布するもの と考えると, 平均的な挙動を示す解析として車両間の相 関を無視した解析を用いることができる. 本解法で算定 した衝撃係数は, 載荷台数が最高 3 台の場合でも, 支䦗 長の增加に伴い急激に減少する.これは車両間の連成効 果によるものであり, 連行車両による橋梁の応答を考え る場合，東雨閒の連成を無視寸ることはできないものと 思われる.

最後に, 本研究を遂行するにあたり, 有明工業高等専 門学校 吉村虎蔵校長, 九州大学 彦坂熙助教授には常に ご指導をいただき，また広島大学 花井正実教授には有 益なご助言とご批判をいただき，ここに梁く感謝の意を 表します.

なお, 本研究の計算には, 九州大学大型計算機センタ 一計算機 (FACOM M 200) および本学情報処理センタ 一計算機（FACOM M 180-2/40）を使用したことを付 記する.

\section{参考文献}

1）山田・小堀：活荷重に対する道路橋の動的応答一衝撃係 数一に関する考察, 士木学会淪文集, No. 148 , pp. 40〜 50,1967 年 12 月.

2）小堀・梶川：単一動荷重に対する道路橋の振動感覚, 土 木学会論文報告集, No. 248, pp. 11 23，1976 年 4 月.

3）吉村・彦坂・内谷：単一走行車两に上る道路橋の非定常 ランダム応答の解析, 土木学会論文報告集, No. 258 , pp. 35 44, 1977 年 2 月.

4）成田・桂樹・江本 : 路面凹凸を考虑した橋梁の衝撃係数, 土木技術資料, Vol. 20, No. 3, pp. 27〜32, 1978 年 3 月.

5) 岡林隆敏 : 単一走行車雨による 道路橋の二乗平均応答解 析, 土木学会論文報告集, No. 286, pp. 15 27, 1979 年: 6 月.

6）岡林隆敏：高次振動を考慮した 道路橋の単一走行車両に 上る非定常 r.m.s. 応答, 士木学会論文報告集, No. 296, pp. 13 24, 1980 年 4 月.

7）川谷・小松：路面不整を含む単純桁橋の走行荷重に上る
非定常不規則振動に関する研究, 上小举:会第 35 约们次学: 術講演会䛾演概要集第 1 部, pp. 323 324, 1980 年 9 月.

8）【日月・小堀：ランダム自動車佃重列に上る道路橋り衝撃 に関与る研究，上林学会論文集，No. 119, pp. 1 9, 1965 年 7 月.

9) Tung, C.C. : Random Response of Highway Bridges to Vehicle Loads, Journal of the Engineering Mechanics Division, ASCE, Vol. 93, No. EM 5, pp. 79 94, October, 1967.

10) Tung, C.C. : Response of Highway Bridges to Renewal Traffic Loads, Journal of the Engineering Mechanics Division, ASCE, Vol. 95, No. EM 1, pp. 41 $\sim 57$, February, 1969.

11) Shinozuka, M. and T. Kobori : Fatigue Analysis of Highway Bridge, Proc. of JSCE, No. 208, pp. 137 148, Dec. 1972.

12) Nakai, H. and H. Kotoguchi : Dynamic Response of Horizontally Curved Girder Bridges under Random Traffic Flows, Proc. of JSCE, No. 244, pp. 117 128, Dec. 1975.

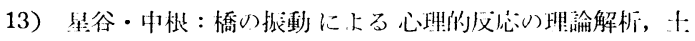

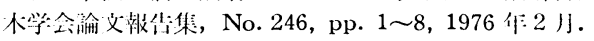

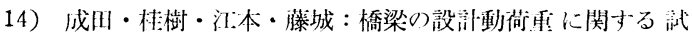

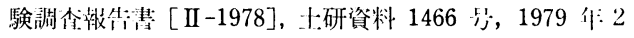
了.

15）桂樹・成田：路面以几に起因与る実働自動車荷重, 上木 学会第 34 回年次学術講演会講演概要集 第 1 部, pp. 479 $\sim 480,1979$ 年 10 月.

16）桂樹・成田：路面凹凸に起因する実働自動車荷重の奏用 推定式, 土木学会第 35 回年次学術講演会講演概要集第 1 部, pp. 321 322, 1980 年 9 月.

17）小松・川谷：斜張橋の自動車.走䘕に上る動的応答々衝撃 係数に関する研究, :木学侌論文報告集, No. 275 , pp. 13〜28, 1978 作 7 ر.

18）梶川逮男：振動感覚を考虑した道路橋の 使用性解析に関

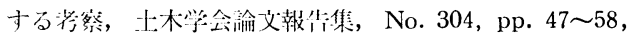
1980 作2 月.

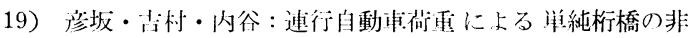

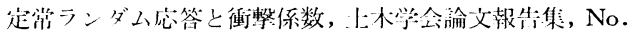
290 , pp. 31 41, 1979 脌 10 J.

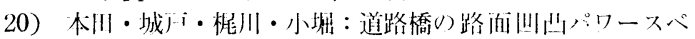

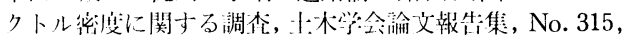
pp.149 155, 1981 作 11 J.

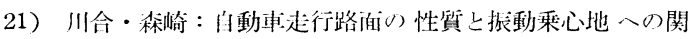
連性，三菱重工技報，Vol. 2, No. 2, pp. 20～28, 1965 件.

22）伊藤 清：確率論，肾波書占，1969 任.

23) Soong, T.T. : Random Differential Equation in Science and Engineering, Academic Press, 1973.

24) Arnold, L. : Stochastic Differential Equation : Theory and Applications, John Wiley and Sons, 1974.

25）日本道路協会：道路橋示方書・闹解説, pp. 8 20, 1973 作 2 月。

(1982.2.2 ·受付) 